\title{
THE ROLE OF LOW MOLECULAR WEIGHT PEPTIDES IN THE REGULATION OF RNA SYNTHESIS IN SCHIZOSACCHAROMYCES POMBE
}

\author{
by \\ BIRTE KRAMHøFT and HELGE A. ANDERSEN \\ Biological Institute of the Carlsberg Foundation, \\ Tagensvej 16, DK-2200 Copenhagen $\mathrm{N}$
}

Keywords: Fission yeast, Tetrahymena inhibitor, actinomycin D

\begin{abstract}
The fission yeast Schizosaccharomyces pombe contains about $30 \%$ more RNA per unit protein when cultivated in a complex broth medium than in a chemically defined, peptide free medium. In cells growing on complex medium the rate of RNA synthesis can be reduced by an inhibitor peptide from the ciliated protozoan Tetrahymena pyriformis. There is no effect on protein synthesis, and the Tetrahymena peptide is without effect on yeast cells in a defined medium. Actinomycin D reduces both RNA and protein synthesis in cells growing on complex as well as defined medium, and the timing of the effect of Actinomycin D and Tetrahymena peptide differs, all suggesting different mechanisms of action of the two peptide inhibitors.

In defined growth medium RNA synthesis can be stimulated by addition of unspecific small peptides. Stimulation of RNA synthesis has no effect on growth rate or cell division rate within the experimental period. We conclude that small peptides in the growth medium specifically stimulate the rate of RNA synthesis in Schizosaccharomyces pombe and that the Tetrahymena peptide inhibits the peptide-induced RNA synthesis.
\end{abstract}

\section{INTRODUCTION}

For some years our laboratory has been engaged in the study of various aspects of regulation of RNA synthesis in the protozoan Tetrahymena pyriformis. In these studies it was observed that Tetrahymena secretes a small peptide which inhibits RNA synthesis in this organism under certain growth conditions $(2,3,4,11)$. Furthermore, it was found that this peptide is active not only in Tetrahymena pyriformis itself and other Tetrahymena species, but also in the fission yeast Schizosaccharomyces pombe, in protoplasts as well as in intact, growing cells $(5,12)$. A striking analogy in the effect of the peptide inhibitor in these very different cells has led to a more detailed study of the effect of small peptides on RNA synthesis in yeast cells under various growth conditions, the results of which is the topic of the present communication.

Our results are to be viewed in the context of the accumulating evidence that low molecular weight peptides play important roles as regula- 
tors in various biological reactions. For example a great number of peptide hormones with low molecular weight are active in the brain, the nervous system and the gastro-intestinal system (for review see ref. 20). Furthermore, some of the regulatory peptides known as chalones have now been relatively well characterized, and the active regulatory components appear to be small peptides with molecular weights around 1,000 daltons (17). Over the last few years a number of reports on the presence of small peptides specifically involved in the regulation of transcription in several mammalian systems have been published. GIANFRANCHESCHI and coworkers have isolated transcription controlling low molecular weight peptides from calf thymus, rat liver and hepatoma cells $(7,10)$ and AMICI et al. have reported the presence of similar peptides in the blood (1).

The present report contributes further information on the role of small peptides in the regulation of RNA synthesis in the fission yeast and supports the concept of the importance of small peptides as regulators in many biological processes.

\section{MATERIALS AND METHODS}

Schizosaccharomyces pombe, haploid strain $972 \mathrm{~h}^{-}$, was kept and propagated as described previously (13). Experimental cultures were grown in Erlenmeyer flasks in a shaking water bath at $32^{\circ} \mathrm{C}$. The media were either a complex broth, YEG, composed of $0.5 \%$ yeast extract (Difco) and $3 \%$ glucose, or chemically defined medium, EMM2, described by Mitchison (15). This medium is a mixture of salts, vitamins, glucose and an inorganic nitrogen source.

Growth rates were assessed by cell counts using a Bürker-Türk hemocytometer. A dividing cell was scored as two when a constriction was clearly observed between two daughter cells (15). Chemical measurement of bulk RNA was carried out by the Orcinol method (19) after hydrolysis in 5\% PCA (perchloroacetic acid) for 2 hours at $37^{\circ} \mathrm{C}$ as suggested by Herbert, PhipPS and Strange (9). Protein was assessed according to LOWRY et al.(14).

RNA and protein synthesis was estimated using the incorporation of radioactive precursors into TCA (trichloroacetic acid) precipitable material. The cultures were labelled with ${ }^{32} \mathrm{P}$ (car- rier free, Risø, Denmark) or ${ }^{14} \mathrm{C}$-leucine (spec.act. $330 \mathrm{mC} \cdot \mathrm{mmol}^{-1}$, Amersham, England) at the time of inocculation, i.e. about 9 cell generations prior to experimental treatment, or at the time of initiation of the experiment. Duplicate samples were drawn at intervals and precipitated with ice cold $10 \%$ TCA to a final concentration of $5 \%$. The samples were then filtered on Whatman GF/C filters, washed three times with 5\% TCA and dried. The amount of radioactive label incorporated into the TCA-insoluble material was counted in a Beckman LS 200 liquid scintillation counter. For further details see text and legends for figures.

Inhibitor peptide from Tetrahymena pyriformis was obtained and partially purified as described by ANDERSEN, LYKKESFELDT and NIELSEN (4). Stock solutions of Actinomycin D (Calbiochem) were made up in water at a concentration of $100 \mu \mathrm{g} \cdot \mathrm{ml}^{-1}$ and kept for no more than two weeks at $5^{\circ} \mathrm{C}$. "Unspecific" peptides (BSA-peptides) were obtained by digesting Bovine Serum Albumine (Sigma) with trypsin (Difco) as described by ANDERSEN et al. (4). Yeast extract was fractionated in the following way: A $20 \%$ solution of yeast extract was passed through a G-25 Sephadex column (Pharmacia). Fractions containing the majority of compounds with molecular weights around those of the peptide compounds used in this study (designated YE I, MW about 1,000 D) were collected and concentrated in a Buichi Rotawapor. Fractions containing low molecular weight substances such as nucleosides and amino acids were discarded. The rest was collected as described above and designated YE II. There is, however, no sharp separation of molecular weight classes between YE I and II. The two yeast extract fractions were used in a final concentration approximately equivalent to their concentration in the complete YEG medium.

\section{RESULTS}

\subsection{Inhibition of transcription by peptides}

As shown previously (12) partially purified Tetrahymena peptide reduced the rate of RNA synthesis in exponentially multiplying yeast cultures. Protein synthesis and cell division rate were not affected. This was observed in cells growing in YEG medium, whereas RNA synthesis of 
B. Kramhøft \& H. A. Andersen: RNA synthesis and fission yeast

Table I

RNA, protein and growth rate of Schizosaccharomyces under various growth conditions.

\begin{tabular}{lccccc}
\hline & \multicolumn{2}{c}{ RNA (pg per cell) } & \multicolumn{2}{c}{ Protein (pg per cell) } & Doubling time \\
& $\begin{array}{c}\text { Stationary } \\
\text { phase cells }\end{array}$ & $\begin{array}{c}\text { Exponentially } \\
\text { multiplying cells }\end{array}$ & $\begin{array}{c}\text { Stationary } \\
\text { phase cells }\end{array}$ & $\begin{array}{c}\text { Exponentially } \\
\text { multiplying cells }\end{array}$ & (min) \\
\hline YEG $^{1}$ & 2 & 4 & 11 & 13 & $90-110$ \\
EMM2 $^{2}$ & 1.4 & 3 & 10 & 13 & $130-150$ \\
\hline
\end{tabular}

1) Yeast extract glucose medium

2) Edinbourgh Minimal Medium No. 2 (15)

yeast cells growing in EMM 2 medium is unaffected by the inhibitor peptide (Figure $4 \mathrm{~A}$ ). In those experiments the inhibitory effect of the peptide was calculated as the difference between the slopes of semilogarithmic plots of phosphate or uracil accumulation in control and treated cultures followed for more than 6 hours or 3 cell generation times.

As shown in Table I, the RNA content per individual cell of exponentially multiplying cultures is about twice the content of stationary phase cells in both media. The lag phase lasts 2-3 hours in this organism, and during this period an accumulation of RNA takes place. Some of this RNA synthesis can be inhibited by the Tetrahymena peptide.

The result of addition of Tetrahymena peptide to stationary phase cultures diluted with fresh media is shown in the experiments depicted in Figures $1 \mathrm{~A}$ and $\mathrm{B}$. In Figure $1 \mathrm{~A}$ a stationary phase YEG culture was diluted 100 fold with fresh YEG medium and the accumulation of ${ }^{32} \mathrm{P}$ and ${ }^{14} \mathrm{C}$-leucine added at time zero was followed with time. It is seen that the Tetrahymena peptide is without effect on leucine incorporation (triangles) whereas phosphate accumulation is reduced to about $75 \%$ of the control value at 3 hours after addition of the peptide (circles). There was no increase in the cell number during the experiment. In contrast to this, it is shown in Figure $1 \mathrm{~B}$ that phosphate accumulation is unaffected by Tetrahymena peptide in a similar experiment with stationary phase cells in EMM 2 medium.

It has been demonstrated by Mitchison and coworkers (16) that the peptide antibiotic Actinomycin D inhibits RNA and protein synthesis in protoplasts of Schizosaccharomyces. We have confirmed this with intact cells growing exponen- tially in YEG medium as shown in Figure 2. Parallel cultures were labelled about 10 generations prior to experimental treatment with either ${ }^{32} \mathrm{P}$ or ${ }^{14} \mathrm{C}$-leucine in order to ensure uniform labelling of the cells. As shown (circles) Actinomycin D $\left(10 \mu \mathrm{g} \cdot \mathrm{ml}^{-1}\right)$ added at time zero, reduces the rate of phosphate incorporation. The rate is reduced by $15-20 \%$ which is equivalent to the degree of inhibition of RNA synthesis obtained by Tetrahymena peptide under identical experimental conditions. In contrast to the results with the Tetrahymena peptide also the rate of leucine incorporation is reduced in the presence of Actinomycin D as shown in Figure 2, lower set of curves. The inhibition of leucine incorporation seems to be delayed by 2 hours compared to the reduction of the rate of phosphate incorporation.

In accordance with the experiment shown in Figure $1 \mathrm{~A}$, Actinomycin D was then added to a stationary phase culture which was diluted with fresh YEG medium. It is seen that under these conditions Actinomycin D also reduced both phosphate and leucine accumulation. The inhibitory effect of the Tetrahymena peptide on RNA synthesis in this experimental system is detectable about 1 hour after addition of the peptide (Figure $1 \mathrm{~A}$ ) whereas with Actinomycin D no inhibition can be observed until about 4 hours after addition or at the time when the cells presumably have resumed exponential growth (Figure 3).

The following conclusions may be drawn from Table I, Figures $1 \mathrm{~A}$ and B and our previous work $(5,12)$ : I) the RNA content of Schizosaccharomyces is much more variable than the protein content and dependent on the growth stage of the culture; II) Schizosaccharomyces contains about 30\% more RNA when grown in YEG medium than in EMM 2, whereas the protein con- 

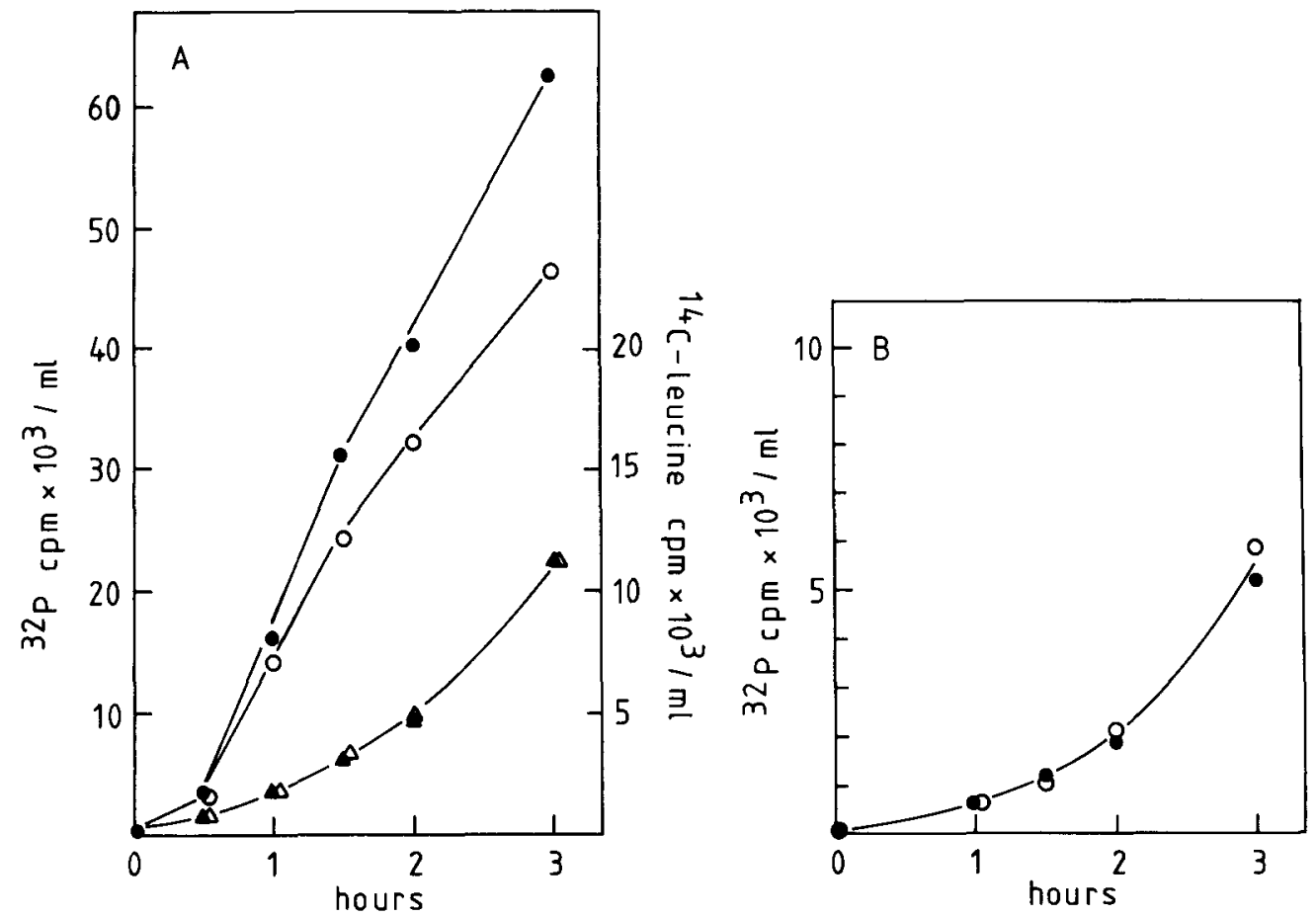

Figure 1. The effect of Tetrahymena peptide on accumulation of RNA and protein with time after transfer of stationary phase cells to fresh growth medium.

Radioactivity $\left(0.2 \mu \mathrm{Ci}\right.$ of ${ }^{32} \mathrm{P} \cdot \mathrm{ml}^{-1}$ or ${ }^{14} \mathrm{C}$-leucine $\left.\cdot \mathrm{ml}^{-1}\right)$ was added at time zero. The culture was divided and distilled water $\left(40 \mu \mathrm{l} \cdot \mathrm{ml}^{-1}\right)$ or Tetrahymena peptide $\left(40 \mu \mathrm{l} \cdot \mathrm{ml}^{-1}\right)$ added to the respective cultures. A: YEG medium.

-: RNA in control; $\bigcirc$ : RNA in culture treated with Tetrahymena peptide; $\Delta$ : protein in control; $\triangle$ : protein in peptide treated culture. B: EMM 2 medium. Symbols as in frame A.

tent is about the same in the two media; III) RNA synthesis can be inhibited by the Tetrahymena peptide only when the cells are

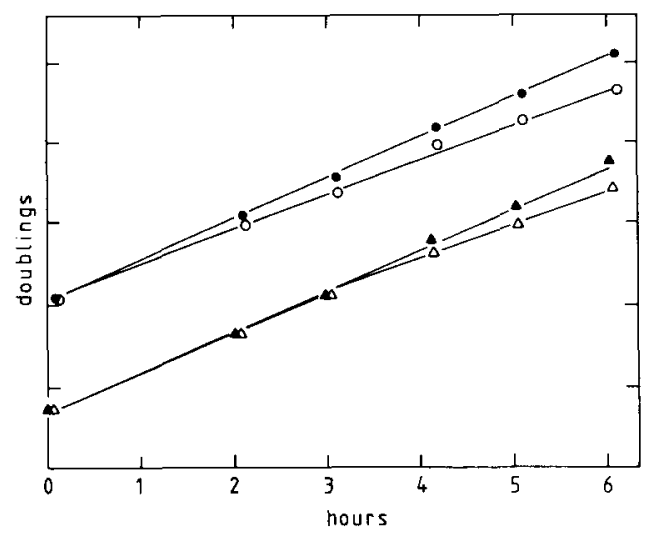

Figure 2. Rate of RNA and protein synthesis in exponentially multiplying cultures treated with Actinomycin $\mathrm{D}\left(10 \mu \mathrm{g} \cdot \mathrm{ml}^{-1}\right)$ at time zero.

Parallel cultures were labelled about 10 generations prior to experimental treatment with $0.04 \mu \mathrm{Ci} \cdot \mathrm{ml}^{-1}{ }^{32} \mathrm{P}$ or $0.1 \mu \mathrm{Ci} \cdot \mathrm{ml}^{-1}{ }^{14} \mathrm{C}$-leucine. Symbols as in Figure 1 . grown in YEG. In this case protein synthesis is unaffected. Actinomycin D inhibits both RNA and protein synthesis and in both media (Figures 2 and 3, (16)); IV) since RNA synthesis may be reduced without affecting protein synthesis, at least part of the extra RNA measured in YEG cells must be in excess. These observations are in agreement with results obtained with the protozoan Tetrahymena pyriformis $(2,4)$.

\subsection{Stimulation of transcription by peptides}

With respect to Tetrahymena, it was suggested that small unspecific peptides present in the rich nutrient broth induced an overproduction of RNA resulting in the presence of excess RNA in these cells when grown in a complex medium (4). This was confirmed by addition of unspecific peptides (BSA-peptides) to Tetrahymena cells growing in a chemically defined medium (4). As demonstrated previously, a striking analogy exists between Tetrahymena and Schizosaccharomyces with respect to the response to 
Tetrahymena peptide $(5,12)$. On this background the effect of unspecific peptides on RNA synthesis in the fission yeast was then assessed. When Schizosaccharomyces is grown in a chemically defined medium (EMM 2) and treated with BSA-peptides the rate of phosphate accumulation is stimulated as shown in Figure $4 \mathrm{~A}$, closed triangles. The new rate of RNA synthesis is attained almost immediately and is about $140 \%$ of the control rate. The stimulation is transient and levels off to normal rate about 2 hours after addition of the peptide. In contrast, Tetrahymena peptide has no effect on the rate of phosphate accumulation in EMM 2 (Figure $4 \mathrm{~A}$, open squares). As shown in the same figure, lower curve, the growth rate is unaffected by both BSA-peptides and Tetrahymena peptide within the experimental period.

As shown in Table I and previous work (12), RNA synthesis as well as growth rate proceed at a faster rate in the YEG medium than in EMM 2 medium (doubling times 110 and $140 \mathrm{~min}$, respectively). Yeast extract is a break down product composed of peptides of various sizes, amino acids, salts and break down products of RNA such as nucleosides. In order to separate a possi-

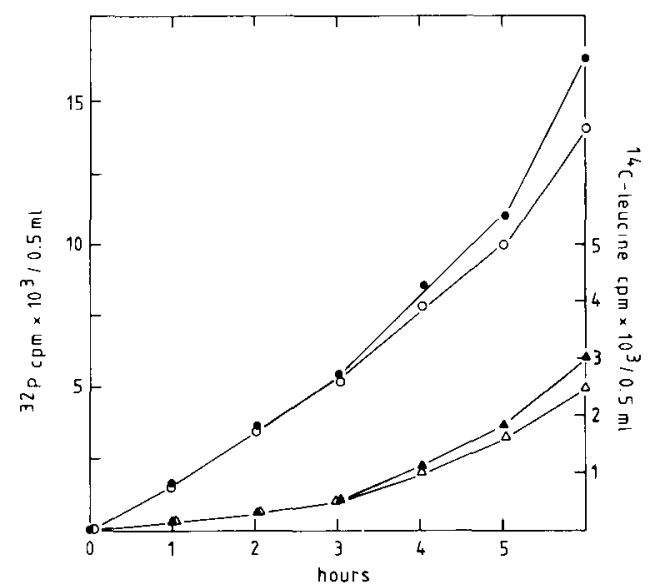

Figure 3. The effect of Actinomycin $D\left(10 \mu \mathrm{g} \cdot \mathrm{ml}^{-1}\right)$ on accumulation of RNA and protein with time after transfer of stationary phase cells to fresh growth medium.

Experimental procedure and symbols as in Figure 1. Radioactivity: $0.25 \mu \mathrm{Ci} \cdot \mathrm{ml}^{-1}$ of ${ }^{32} \mathrm{P}$ and ${ }^{14} \mathrm{C}$-leucine.

le effect of peptidic compounds in the YEG medium from the effect of low molecular weight compounds such as amino acids and nucleosides, the yeast extract was "fractionated" as described in section 2. The effect of addition of the two yeast extract fractions to cells growing in EMM 2

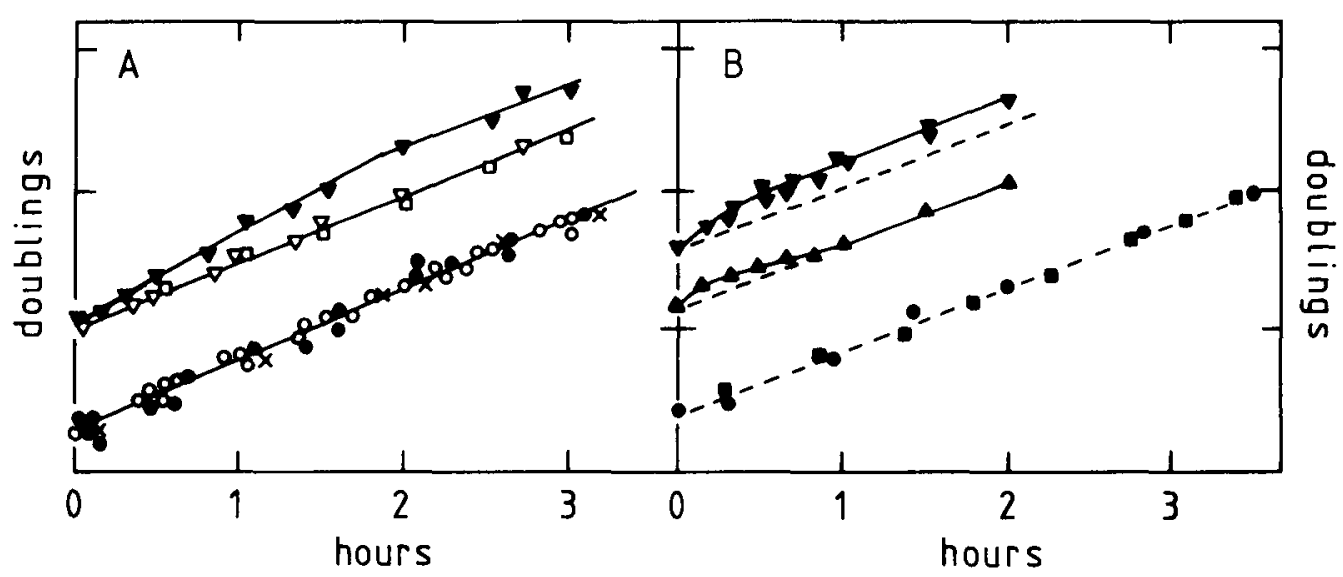

Figure 4. Rate of RNA synthesis and cell division in exponentially multiplying cultures in EMM 2 medium treated with various peptide preparations.

Experimental procedure as in Figure 2. A: BSA-peptides and Tetrahymena peptide. Upper set of curves: ${ }^{32} \mathrm{P}$ incorporation. Control: $\nabla ;$ BSA-peptides $\left(130 \mu \mathrm{g} \cdot \mathrm{ml}^{-1}\right)$ : $\nabla$ and Tetrahymena peptide $\left(40 \mu \mathrm{l} \cdot \mathrm{ml}^{-1}\right): \square$. Lower set of curves: Cell number. Control: $O$; BSA-peptides: - and Tetrahymena peptide: $\times$. B: Peptide fractions from yeast extract. $\nabla, \triangle:{ }^{32} \mathrm{P}$ accumulation with time in fractions I and II, respectively. The broken lines represent the rate of phosphate accumulation in control cultures. ${ }^{32} \mathrm{P}\left(0.1 \mu \mathrm{Ci} \cdot \mathrm{ml}^{-1}\right)$ was added at the time of inoculation. Peptides from yeast extract was added in amounts equivalent to complete YEG medium. Lower set of curves $(\boldsymbol{\square}, \bullet)$ show cell number in the two cultures. 
Table II

Stimulation of RNA synthesis by unspecific peptides in Scizosaccharomyces grown in EMM 2.

\begin{tabular}{|c|c|c|c|c|c|}
\hline & Control & $\begin{array}{l}\text { Tetrahymena } \\
\text { peptide }\end{array}$ & $\begin{array}{c}\text { BSA } \\
\text { peptides }\end{array}$ & $\begin{array}{l}\text { Fractionatec } \\
\text { fractions I }\end{array}$ & $\begin{array}{l}\text { ast extract } \\
\text { fractions II }\end{array}$ \\
\hline $\begin{array}{l}\text { Maximum rate of } \\
\text { RNA synthesis } \\
\text { Duration of }\end{array}$ & $100 \%$ & $100 \%$ & $137 \%$ & $173 \%$ & $144 \%$ \\
\hline stimulation & - & - & $120 \mathrm{~min}$ & $30 \mathrm{~min}$ & $10 \mathrm{~min}$ \\
\hline
\end{tabular}

medium is shown in Figure $4 \mathrm{~B}$, the two upper curves. It is seen that YE I stimulated phosphate incorporation immediately, the stimulation lasting about $30 \mathrm{~min}$ whereafter the rate returns to normal. YE II results in a small stimulation of short duration. The broken lines indicate the rate of RNA synthesis in control cultures. The two yeast extract preparations have no effect on cell multiplication rates as shown in Figure 4 B, lower curve. The stimulatory effect of the various peptide preparations is summarized in Table II.

Figure 5 shows the effect of increasing concentrations of BSA peptides on stimulation of the rate of phosphate accumulation in yeast cells growing in EMM 2 medium. It is seen that there is no stimulation below $50 \mu \mathrm{g} \cdot \mathrm{ml}^{-1}$ whereas peptide concentrations above $100 \mu \mathrm{g} \cdot \mathrm{ml}^{-1}$ all have maximum stimulatory effect.

As mentioned previously, the growth rate of

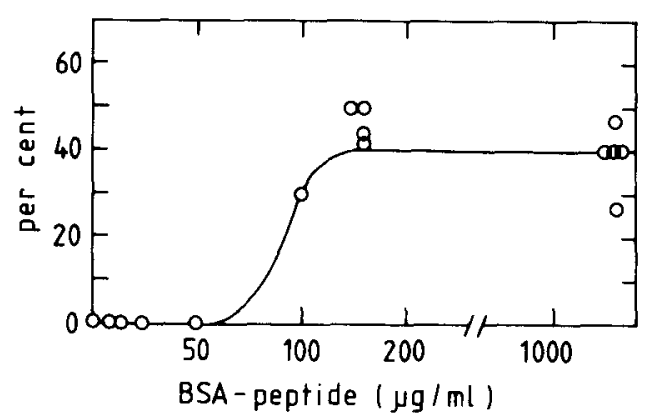

Figure 5. Percentage increase in the rate of RNA synthesis as a function of the concentration of BSA-peptides.

Cultures were labelled with ${ }^{32} \mathrm{P}\left(0.1 \mu \mathrm{Ci} \cdot \mathrm{ml}^{-1}\right)$ at the time of inoculation. About 9 generations later the culture was subdivided and various amounts of BSA peptides were added and the relative increase in the rate of phosphate accumulation compared to controls was calculated. cells in YEG medium is faster than in EMM 2 medium. As demonstrated above neither of the yeast extract fractions had any effect on growth rate (Figure $4 \mathrm{~B}$ ). Consequently, low molecular weight substances present in the yeast extract powder are likely to be involved in supporting the faster growth seen in this medium. Accordingly, a mixture of amino acids and nucleosides prepared according to RASMUSSEN and MODEWEGHANSEN (18) for a Tetrahymena medium was added to yeast cells growing in EMM 2. The result is shown in Figure 6. The nucleoside-amino acid mixture has no immediate effect on the rate of phosphate accumulation (triangles). Not until about 1.5 hours after addition of the mixture the rate of RNA synthesis changes and then to the rate characteristic of cells growing in YEG. This rate change is accompanied by a similar change in growth rate as shown in Figure 6, closed circles in lower set of curves. This set of curves also shows the effect on growth rate of addition of yeast extract powder to a culture growing in EMM 2 medium (closed squares). It is seen that the growth rate changes in parallel to the culture treated with the amino acid-nucleoside mixture.

\section{DISCUSSION}

The results presented above confirm the assumption that a low molecular weight peptide, secreted by the protozoan Tetrahymena pyriformis, represses RNA synthesis in phylogenetically distant organisms such as the fission yeast. Furthermore, we have demonstrated that other small peptides stimulate RNA synthesis in this yeast, supporting the hypothesis of the existence of analogous RNA regulatory mechanisms in the two organisms as previously suggested $(4,5,12)$.

In the present study ${ }^{32} \mathrm{P}$ was used as an indicator of RNA synthesis. The reason for this was 
that uracil cannot be used as RNA precursor in experiments in which stimulation of RNA synthesis is to be studied since pool variations of uracil (and uridine) will influence the incorporation (B. KramhøFt and H.A. ANDERSEN, to be published). Schizosaccharomyces will utilize exogenous RNA precursors such as uracil when present, and will also synthesize uracil from inorganic nitrogen. Stimulation of RNA synthesis in yeast cells growing in a defined medium with an inorganic nitrogen source as in EMM 2 will, other things being equal, increase the rate of endogenous uracil synthesis resulting in a reduction of the specific activity of the uracil "pool"; hence a reduced incorporation of uracil into TCA-insoluble material of the cell follows stimulation of the RNA synthesis. As shown elsewhere (12) Tetrahymena peptide reduces both phosphate and uracil incorporation and to the same extent in exponentially growing cells, whereas leucine incorporation and cell division rate are unaffected. This excludes an effect of the Tetrahymena peptide on other cellular macromolecules such as protein, lipids or DNA into which ${ }^{32} \mathrm{P}$ is also incorporated, and strongly suggests that changes in phosphate accumulation reflect specific effects on RNA synthesis.

Actinomycin $\mathrm{D}$ is known to be a highly specific inhibitor of RNA polymerases and in low concentrations to inhibit polymerase I preferentially (6). The effect of Actinomycin D has also been demonstrated in protoplasts of Schizosaccharomyces (16), and it has been suggested that the action of Tetrahymena peptide is on the transcription of ribosomal RNA in Tetrahymena (4). The present results suggest that the two RNA inhibitors may repress the transcription of different species of RNA. This assumption is based on the fact that Actinomycin D in both organisms reduces RNA and protein synthesis, whereas the Tetrahymena peptide only reduces RNA synthesis. It thus follows that the site of action of the Tetrahymena peptide must be the transcription of RNA not involved in protein synthesis, i.e. on excess RNA. Furthermore, Actinomycin D, but not Tetrahymena peptide, affects RNA synthesis in yeast cells growing in the defined medium (16). This supports the hypothesis that cells growing in complex medium accumulate excess RNA, the transcription of which is the target of

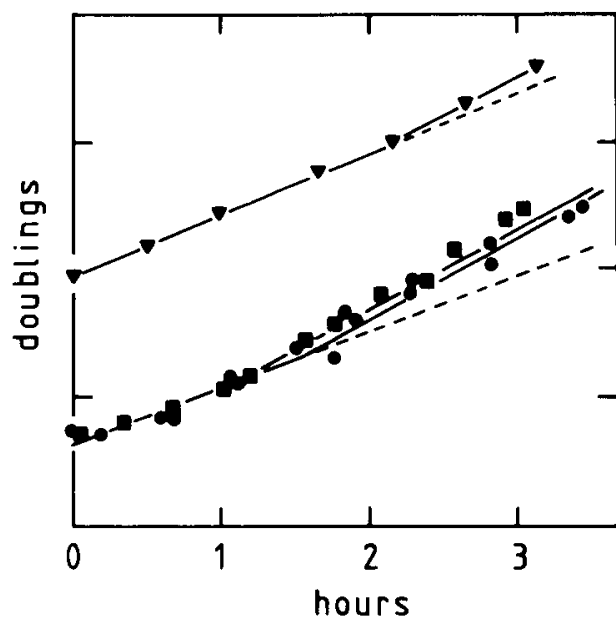

Figure 6. Rate of RNA synthesis and cell division in EMM 2 cultures treated with a nucleoside-amino acid mixture.

Experimental procedure and radioactivity as in Figure 4. $\nabla$ : ${ }^{32} \mathrm{P}$ accumulation; $\boldsymbol{O}$ cell number. $\boldsymbol{\nabla}$ : cell number in a parallel culture treated with complete yeast extract powder. The broken lines show the division rate of untreated controls.

the Tetrahymena peptide. In contrast, Actinomycin D may act on "normal" ribosomal RNA synthesis. This suggestion is supported also by the observation (Figure 2) that the inhibitory action of Actinomycin D in exponentially multiplying cells is detectable from about 1 hour after addition, followed later by an inhibition of protein synthesis. However, in stationary phase cells, diluted with fresh medium (Figure 3 ) no effect was observed until after the lag phase and then RNA and protein synthesis were affected simultaneously. The effect of the Tetrahymena peptide is detectable about 1 hour after addition in both systems.

If excess RNA is accumulated as a consequence of the presence of stimulatory peptides in the complex medium, a stimulation of RNA synthesis would be expected in cells growing in the defined medium treated with unspecific peptides. This was also the case as shown in Figures 4 A and B, Figure 5 and Table II. The observed degree of stimulation is rather high but only transitory, and RNA synthesis is stimulated without any effect on growth rate within the experimental period (Figures $4 \mathrm{~A}$ and $\mathrm{B}$ ). The stimulated rate of RNA synthesis cannot be sustained unless low molecular weight substances as in the com- 
plete yeast extract medium are also present. As shown in Figure 6 addition of nucleosides and amino acids to cells growing in EMM 2 medium leads to a stimulation of growth rate followed later by an increased rate of phosphate accumulation. These observations indicate that small peptides are involved in the stimulation of transcription, but low molecular weight substances are necessary for the maintenance of the stimulated rate of RNA synthesis. Thus, RNA synthesis may be stimulated without effect on cell division rate, and conversely, cell division rate may be stimulated without any immediate effect on RNA synthesis (Figure 6). Consequently, growth (cell division rate) and RNA synthesis are not strictly coupled in the fission yeast as is the case in bacteria.

The Tetrahymena peptide is secreted by the cells to the surrounding medium from which it can be isolated. So far we have not been able to demonstrate the existence of an inhibitor in the yeast medium. However, Gianfrancheschi et al. (8) have recently reported on the isolation of low molecular weight RNA inhibitory peptides from the chromatin of Saccharomyces. Thus the results presented here support the hypothesis previously proposed $(4,5,12)$ that small peptides play a general role in the regulation of RNA synthesis in eukaryote cells.

\section{ACKNOWLEDGEMENTS}

We wish to thank Mrs. Lisbeth Faldborg PeTERSEn and Mrs. Helga Langelo Sørensen for expert technical assistance.

\section{REFERENCES}

1. Amici, D., F. Cicconi, O. Murri, M. Hillar \& G.L. Gianfranceschi: Small peptides controlling DNA transcription are present in the blood. IRCS Medical Sciences 8, 712 (1980)

2. ANDERSEN, H.A. \& S.J. Nielsen: Regulation of RNA synthesis in Tetrahymena pyriformis: Secretion of regulatory factors. J. Cell Sci. 35, 17-24 (1979)

3. ANDERSEN, H.A. \& A.E. LyKKeSfeldT: Tetrahymena cells secrete a low molecular weight factor which inhibits RNA synthesis in vivo and in vitro. Cell Biol. Internat. Rep. 3, 8591 (1979)
4. Andersen, H.A., A.E. Lykkesfeldt \& S.J. NiELSEN: On the role of small peptides in the regulation of RNA synthesis in Tetrahymena pyriformis. J. Cell Sci. 45, 31-39 (1980)

5. Andersen, H.A. \& B. Kramhøft: Inhibition of RNA synthesis in yeast protoplasts by a peptide factor from Tetrahymena cells. Cell Biol. Internat. Rep. 5, 187-194 (1981)

6. Busch, H. \& K. Smetana: The nucleolus. Academic Press, New York and London (1970)

7. Gianfrancheschi, G.L., L. Guglielmi, D. Amici, F. Bossa, D. Barra \& P. Petruzzelli: Low molecular weight peptides controlling transcription are present in the calf thymus chromatin structure. Mol. Biol. Rep. 3, 429436 (1977)

8. Gianfrancheschi, G.L., D. Barra, F. Cicconi, S. Coderoni, F. Venanzi \& D. Amici: Small chromosomal peptides are involved in the regulation of chromatin DNA transcription. Abstract No. 1 from Ist Internat. Symp. on Regulation of Gene Expression by low molecular weight peptides. Universitá della Calabria, Italy (1982)

9. Herbert, P., P.J. Phipps \& R.E. Strange: Chemical analysis of microbial cells. In: Methods in Microbiology, J.R. Norris \& D.W. Ribbons eds., Academic Press, New York and London Vol. 513 pp. 308-328 (1971)

10. Hillar, M. \& J. Przyjemski: Nuclear deprimerones in rat liver and Novikoff hepatoma. Mol. Biol. Rep. 6, 67-71 (1979)

11. Keiding, J. \& H.A. Andersen: Regulation of ribosomal RNA synthesis in Tetrahymena pyriformis. J.Cell Sci. 31, 13-23 (1978)

12. KRAMHøFt, B. \& H.A. ANdersen: Regulation of RNA synthesis in fission yeast. The effect of a Tetrahymena peptide factor on RNA synthesis in exponentially multiplying yeast cells. Cell Biol. Internat. Rep. 5, 1019-1025 (1981)

13. KRAMHøFT, B. \& E. ZeUthen: Synchronization of cell division in the fission yeast Schizosaccharomyces pombe using heat shocks. Compt. Rend. Trav. Lab. Carlsberg 38, 351-368 (1971)

14. Lowry, O.H., N.J. Rosenbrough, A.L. FarR \& R.J. RANDALl: Protein measurement with the folin phenol reagent. J. Biol. Chem. 193, 265-271 (1951)

15. Mrtchison, J.M.: Physiological and cytological methods for Schizosaccharomyces pombe. In: Methods in Cell Physiol, D.M. Prescott ed., Academic Press, New York and London Vol. 4 pp. 131-165 (1970)

16. Mitchison, J.M., J. Creanor \& M.L. SarTIRANA: Enzyme synthesis, RNA synthesis and 
B. Kramhøft \& H. A. Andersen: RNA synthesis and fission yeast

the effect of Actinomycin D in protoplasts of the fission yeast Schizosaccharomyces pombe. In: Yeast, Mold and Plant Protoplasts, J.R. Villanueva, J. Garcia-Acha, S. Bascón \& F. Uruburu eds., Academic Press, New York and London pp. 229-247 (1973)

17. PatT, L.M. \& J.C. Houck: The incredible shrinking chalone. FEBS Letters 120, 163-170 (1980)
18. Rasmussen, L. \& L. Modeweg-Hansen: Cell multiplication in Tetrahymena cultures after addition of particulate material. J. Cell Sci. 12, 275-286 (1973)

19. Schneider, W.S.: Phosphorous compounds in animal tissues. J. Biol. Chem. 161, 293-303 (1945)

20. Schwyzer, R.: Peptides and the new endocrinology. Naturwissenschaften $69, \quad 15-20$ (1982) 